\title{
Outcome of frontalis suspension surgery in pediatric ptosis
}

\author{
Safinaz Mohd Khialdin ${ }^{1,2}$, Frank J. Martin ${ }^{1,3}$, Michael Jones', \\ Craig Donaldson ${ }^{1}$ \\ 'Department of Ophthalmology, The Children's Hospital at Westmead, \\ Westmead, Australia; '2 Department of Ophthalmology, Faculty of Medicine, \\ Universiti Kebangsaan Malaysia Medical Center, Cheras, Malaysia; ${ }^{3}$ Department \\ of Ophthalmology, University of Sydney, Sydney, Australia
}

\begin{abstract}
Purpose: To describe the outcome of pediatric ptosis surgery using frontalis suspension technique.

Design: Retrospective study.

Methods: All patients with ptosis who underwent frontalis suspension from April 2009 to April 2014 at the Children's Hospital at Westmead were included. Medical records of patients were reviewed and analyzed.

Results: A total of 55 patients (74 primary procedures) were included in the study. Sixtyeight procedures (91.9\%) used silicone as frontalis suspension material, three procedures used Gore-Tex, and three procedures used fascia lata. For procedures using silicone, the recurrence rate was $10.29 \% ; 4.41 \%$ had infection and $1.47 \%$ had exposure keratopathy. All three procedures using Gore-Tex developed postoperative infection. No postoperative complication was documented in all the three procedures using fascia lata.

Conclusion: A change in the practice from using banked fascia lata to silicone as frontalis suspension material is seen at the Children's Hospital at Westmead. The postoperative complications and recurrence rate in procedures using silicone are relatively low. Autologous fascia lata could be considered as an alternative for older children in view of its long-term success rate and fewer complications.
\end{abstract}

Keywords: fascia lata, frontalis suspension, pediatric, ptosis surgery, silicone

\section{Introduction}

Ptosis is characterized by drooping of the upper eyelid margin to an abnormally low position on the anterior surface of the eye. It is most commonly classified as congenital or acquired. Most congenital ptosis is associated with levator dystrophy, which has poor levator function. Thus, the preferred method of surgery is frontalis suspension. The frontalis suspension technique was first described

Correspondence: Safinaz Mohd Khialdin, Department of Ophthalmology, Faculty of Medicine, Universiti Kebangsaan Malaysia Medical Center, Jalan Yaacob Latif, Bandar Tun Razak, 56000 Cheras, Malaysia.

Email: drsafinaz1978@yahoo.com.my 
by Hess in 1893 for the correction of ptosis and its principles remain relevant to this day.

Ptosis surgery is often delayed to a later age as congenital ptosis typically improves somewhat with time. There is also the added advantage that a more accurate assessment is often attainable in older children. Later surgery also allows further development of the orbital structures and decreases the anesthetic risk in children; however, the presence or risk of amblyopia may warrant early surgical correction in the younger age group. Age at the time of ptosis surgery may influence the type of frontalis suspension material used.

Several materials are available for frontalis suspension surgery. Autologous fascia lata is considered by many as the gold standard in frontalis suspension surgery. ${ }^{1,2}$ Other alternatives include banked fascia lata or synthetic material such as silicone, Gore-Tex, and Ethibond. ${ }^{3,4}$ These individual materials have their own advantages and disadvantages. Surgeons have reported a preference for using silicone slings for its flexibility and elasticity., 5 Gore-Tex implants have been associated with infection and granuloma formation. ${ }^{7-9}$ We conducted a retrospective study on patients who had undergone frontalis suspension surgery at the Children's Hospital at Westmead between 2009 and 2014. We report the types of suspension material used, rate of recurrence, and postoperative complications.

\section{Methods}

This retrospective study analyzed the medical records of all patients with ptosis who underwent frontalis suspension from April 2009 to April 2014. Ethical approval was acquired from the Sydney Children's Hospitals Network Human Research Ethics Committee and conformed to the requirements of the United States Health Insurance Portability and Privacy Act. Details that might disclose the identity of the subjects under the study have been omitted. All patients had undergone an ophthalmic and orthoptic evaluation prior to surgery. All patients had undergone frontalis suspension surgery using the Fox procedure. $^{10}$

Satisfactory functional and cosmetic success was defined as the patient having adequate lift (lids not covering visual axis in primary position) and not having ptosis recurrence nor any postoperative complications.

\section{Results}

There was a total 64 patients (87 procedures) who had undergone primary ptosis correction using the frontalis suspension technique. Nine patients ( 13 procedures) were excluded due to duration of follow-up being less than 6 months, leaving a total of 55 patients (74 procedures) included in the study; 38 patients were male 
and 17 patients were female. The most common etiology was simple congenital ptosis (49 patients). The remaining were blepharophimosis (4 patients), Kabuki syndrome (1 patient), and Marcus Gunn jaw-winking syndrome (1 patient).

In this study, patients first presented with ptosis at a mean age of 19.3 months, ranging from 1 month to 9 years. The mean age at the time of surgery was 46.2 months. Patients with follow-up of six months or more were included in this study. The mean duration of follow-up was 30.6 months. The longest follow-up duration was 5 years (Table 1).

Table 1. Age at presentation and surgery

\begin{tabular}{|l|l|l|l|}
\hline & Mean (months) & $\begin{array}{l}\text { Standard error } \\
\text { of mean }\end{array}$ & Range \\
\hline Age at presentation & 19.34 & 4.71 & 1 month-9 years \\
\hline Age at time of surgery & 46.17 & 4.75 & 1.5 months-13 years \\
\hline Duration of follow-up & 30.62 & 2.28 & 6 months-5 years \\
\hline
\end{tabular}

The preferred suspension material used for ptosis surgery was silicone, which accounts for $91.9 \%$ of all primary procedures (Table 2). The success rate among the primary procedures using silicone was $82.35 \%$. Among the total of 68 primary procedures using silicone, 7 cases developed recurrence of ptosis, 3 cases had infection, 1 case had exposure keratopathy, and 1 case had sling extrusion. There were only three cases using Gore-Tex and all three cases developed infection. None of the cases using fascia lata was reported to have ptosis recurrence or postoperative complications (Table 3).

For secondary procedures, there was a total of 13 patients ( 14 procedures). The mean age at the time surgery was performed was 10.72 years (range from 6 to 14 years). Silicone suspension was used in 11 procedures, Gore-Tex in 2 procedures, and 1 procedure used fascia lata. Only 4 out of 13 patients who had undergone secondary procedures had a follow-up longer than 4 months.

Table 2. Type of frontalis suspension material

\begin{tabular}{|l|l|l|}
\hline Types of suspension material & Total procedures & $\%$ \\
\hline Silicone & 68 & 91.9 \\
\hline Gore-Tex & 3 & 4.05 \\
\hline Fascia lata & 3 (2 Autologous, 1 Banked) & 4.05 \\
\hline
\end{tabular}


Table 3. Outcome and complications in primary procedures

\begin{tabular}{|l|l|l|l|}
\hline & $\begin{array}{l}\text { Silicone } \\
(\mathbf{n}=\mathbf{6 8})\end{array}$ & $\begin{array}{l}\text { Gore-Tex } \\
(\mathbf{n}=\mathbf{3})\end{array}$ & $\begin{array}{l}\text { Fascia lata } \\
(\mathbf{n}=\mathbf{3})\end{array}$ \\
\hline Satisfactory outcome & $56(82.35 \%)$ & $0(0 \%)$ & $3(100 \%)$ \\
\hline Ptosis recurrence & $7(10.29 \%)$ & 0 & 0 \\
\hline Complications & & & \\
\hline Infection & $3(4.41 \%)$ & $3(100 \%)$ & 0 \\
\hline Exposure keratopathy & $1(1.47 \%)$ & 0 & 0 \\
\hline Sling extrusion & $1(1.47 \%)$ & 0 & 0 \\
\hline
\end{tabular}

\section{Discussion}

The striking result in this study was the prevalence of the use of silicone suspension at this pediatric institute. Over the 5 -year period studied, more than $90 \%$ of the primary procedures performed in this center used silicone as the material in frontalis suspension surgery. Hersh et al. reported $63.8 \%$ of primary ptosis procedures used banked fascia lata and only $36.2 \%$ used silicone at the same center prior to 2005, highlighting a change in the practice of preferred frontalis suspension material. ${ }^{3}$

As noted, in contrast to Hersh et al., only 3 out of 74 procedures used fascia lata during our study period. Two of the implants were autologous fascia lata, hence requiring harvesting procedure during the ptosis surgery. The patients were all older than 10 years, making it feasible to harvest the fascia lata. Autologous fascia lata has the best long-term results in conserving a good lid position postoperatively, with fewest complications. ${ }^{2}$ Despite having a good functional outcome, autologous fascia lata also has its limitations. The child has to be old enough so that sufficient length of tissue can be harvested. The child can suffer from a hematoma formation or left with a nasty scar or keloid at the donor site. ${ }^{11}$ The use of autologous fascia lata would also necessitate a longer anesthetic time given the harvesting of tissue.

Another option to harvesting autologous fascia lata is using banked fascia lata. As observed, only one procedure in this study used banked fascia lata. Banked fascia lata is biological material and, as such, always carries some risk of disease transmission. Previous reports have revealed cases involving transmission of viruses after transplantation of banked tissue. ${ }^{12-14}$ Patients infected with Creutzfeldt-Jacob disease have also been reported after corneal transplant. ${ }^{15,16}$ Banked tissues undergo a meticulous process of either freeze-drying or irradiation, or a combination of the two methods, in order to remove the genetic substance in the tissues. This is to avoid the transmission of infectious agents 
in the tissues when being transplanted. Despite these preventive measures, a study has shown that freeze-dried gamma-irradiated cadaveric donor tissue still contained intact deoxyribonucleic acid. ${ }^{17}$ These risks may be the reason banked fascia lata has been less favorably used as the choice for suspension material.

As surgery needs to be performed as early as possible in cases with possible risk of amblyopia, synthetic suspension materials need to be utilized in younger children. Silicone is one of the suspension materials of choice and is the preferred material used in this study. Silicone is readily available and easily accessed by surgeons. Silicone has been used widely in many centers as it has been tested to be effective in the treatment of ptosis. ${ }^{18}$ Silicone was one of the earliest suspension materials described by Tillet and Tillet in 1963 using a No. 40 silicone strip. ${ }^{19}$ All six patients described by Tillet and Tillet had good results after 19 to 24 months follow-up. ${ }^{19}$ Silicone was found to be superior to all other materials in a study by Lamont and Tyers in regard to easily adjusting the suspension material. ${ }^{20}$ Due to this property of easy adjustability, it is a reasonable material choice if recurrence occurs. It may also be easily revised or replaced if the intended lid position was not attained after the primary surgery due either to under- or overcorrection or recurrence of ptosis. Silicone suspension does not incorporate with surrounding collagenous tissue, making it easier to remove or adjust. Its elasticity is another advantage, making it possible for patients to close the eye against the tension of the suspension while still maintaining an acceptable lid height. This would reduce the risk of exposure keratopathy. Several other studies have reported recurrence and complication rates when using silicone in ptosis surgery (Table 4). The recurrence rate in our study was comparable to previous reports, while the rate of infection and exposure keratopathy was comparatively low. The recurrence rate in previous studies seems to vary widely. Different study design and definition of terms may cause this variation. However, all studies did report cases of infection, which is not surprising given a foreign material is being implanted. Comparison for fascia lata and Gore-Tex was not done, as the numbers of procedures in our study were too small.

Gore-Tex (polytetrafluoroethylene suture) was used in 3 out of 74 procedures during this study period. It is a heterologous material that has been used in brow suspension surgery since $1986 .{ }^{22}$ All three cases in our study were complicated with infection and granuloma. In 2001, Steinkogler reported that 5 out of $11(45.5 \%)$ needed removal of Gore-Tex for suspected infection. ${ }^{27}$ Another study also reported a $40 \%$ complication rate in procedures using Gore-Tex. ${ }^{9}$ The complications reported include ptosis recurrence and granuloma formation. This high percentage of infection and granuloma formation may be attributed to the porous feature of Gore-Tex, which may allow an influx of pathogens leading to infection. 
Table 4. Comparison of complication rates using silicone with previous studies

\begin{tabular}{|c|c|c|c|c|c|c|c|c|}
\hline & $\begin{array}{l}\text { Our } \\
\text { study }\end{array}$ & $\begin{array}{l}\text { Bansal and } \\
\text { Sharma }^{21}\end{array}$ & $\begin{array}{l}\text { Khan } \\
\text { et al. }\end{array}$ & $\begin{array}{l}\text { Ali } \\
\text { et al. }{ }^{23}\end{array}$ & $\begin{array}{l}\text { Horng } \\
\text { et al. }{ }^{24}\end{array}$ & $\begin{array}{l}\text { Morris } \\
\text { et al. }{ }^{25}\end{array}$ & $\begin{array}{l}\text { Hersh } \\
\text { et al. }{ }^{3}\end{array}$ & $\begin{array}{l}\text { Simon } \\
\text { et al. }{ }^{26}\end{array}$ \\
\hline Type of study & $\mathrm{R}$ & $\mathrm{R}$ & $P$ & $P$ & $\mathrm{R}$ & $\mathrm{R}$ & $\mathrm{R}$ & $\mathrm{R}$ \\
\hline $\begin{array}{l}\text { Number of } \\
\text { procedures (n) }\end{array}$ & 68 & 38 & 15 & 35 & 49 & 110 & 46 & 34 \\
\hline Recurrence (\%) & 10.3 & 2.63 & 7 & 2.8 & 0 & $--^{\mathrm{a}}$ & 13 & 44 \\
\hline $\begin{array}{l}\text { Infection/ } \\
\text { granuloma (\%) }\end{array}$ & 4.41 & 7.89 & 7 & 2.8 & 2.04 & 1.81 & 15.2 & 7.41 \\
\hline $\begin{array}{l}\text { Exposure } \\
\text { keratopathy (\%) }\end{array}$ & 1.47 & $--^{a}$ & $--^{\mathrm{a}}$ & $--^{\mathrm{a}}$ & 18.0 & 3.63 & $--^{a}$ & $--^{a}$ \\
\hline $\begin{array}{l}\text { Sling extrusion/ } \\
\text { exposure (\%) }\end{array}$ & 1.47 & 7.89 & 7 & $-^{\mathrm{a}}$ & 4.08 & $-^{\mathrm{a}}$ & 15.2 & 3.73 \\
\hline Lagophthalmos (\%) & $--^{\mathrm{a}}$ & 13.1 & $--^{\mathrm{a}}$ & $--^{a}$ & $--^{\mathrm{a}}$ & $--^{\mathrm{a}}$ & $-^{\mathrm{a}}$ & $--^{\mathrm{a}}$ \\
\hline $\begin{array}{l}\text { Under } \\
\text { correction (\%) }\end{array}$ & $--^{\mathrm{a}}$ & 10.52 & 26 & $--^{a}$ & $--^{a}$ & 9 & $--^{a}$ & $--^{a}$ \\
\hline $\begin{array}{l}\text { Chronic eyelid } \\
\text { edema (\%) }\end{array}$ & $--^{a}$ & 2.63 & $-^{a}$ & $--^{\mathrm{a}}$ & $--^{\mathrm{a}}$ & $--^{a}$ & $--^{a}$ & $--^{a}$ \\
\hline
\end{tabular}

P: Prospective study; R: retrospective study;

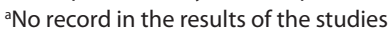

At the Children's Hospital in Westmead, there has been a move away from stored fascia lata to the use of silicone as the choice of material for ptosis surgery. The recurrence rate with silicone is slightly lower (10.29\% vs. $13 \%$ ) and rate of infections/ granuloma is significantly lower (4.1\%) compared to compared to $15.2 \%$ in the Hersh et al. ${ }^{3}$ study.

\section{Conclusions}

Silicone is the preferred choice of material used for frontalis suspension surgery for ptosis at the Children's Hospital at Westmead. The complication and recurrence rates are relatively low. Silicone allows for easy removal and adjustability where indicated. Autologous fascia lata could be considered as an alternative for older children in view of its long-term success rate and few complications. 


\section{Acknowledgments}

The authors thank the participating ophthalmologist at the Children's Hospital at Westmead (Westmead, Australia) in assisting with the data collection.

\section{References}

1. Crawford JS. Repair of ptosis using frontalis muscle and fascia lata: a 20-year review. Ophthalmic Surg. 1977;8:31-40.

2. Wagner RS, Mauriello JA, Nelson LB, Calhoun JH, Flanagan JC, Harley RD. Treatment of congenital ptosis with frontalis suspension: a comparison of suspensory materials. Ophthalmology. 1984;91:245-248.

3. Hersh D, Martin FJ, Rowe N. Comparison of silastic and banked fascia lata in pediatric frontalis suspension. J Pediatr Ophthalmol Strabismus. 2006;43:212-218.

4. Bajaj MS, Sastry SS, Ghose S, et al. Evaluation of polytetrafluoroethylene suture for frontalis suspension as compared to polybutylate-coated braided polyester. Clin Exp Ophthalmol. 2004;32:415-419.

5. Bernardini FP, de Conciliis C, Devoto MH. Frontalis suspension sling using a silicone rod in patients affected by myogenic blepharoptosis. Orbit. 2002;21(3):195-198.

6. van Sorge AJ, Devogelaere T, Sotodeh M, Wubbels R, Paridaens D. Exposure keratopathy following silicone frontalis suspension in adult neuro- and myogenic ptosis. Acta Ophthalmol. 2012;90:188-192.

7. Chan JB, Abdul Rahman N, Palani SK, Embong Z, Qamaruddin F. Infected ptosis surgery: a rare complication from multidrug-resistant organism. Clin Ophthalmol. 2015;9:721-724.

8. Wasserman BN, Sprunger DT, Helveston EM. Comparison of materials used in frontalis suspension. Arch Ophthalmol. 2001;119:687-691.

9. Junceda-Moreno J, Sußrez-Sußrez E, Dos-Santos-Bernardo V. Treatment of palpebral ptosis with frontal suspension: a comparative study of different materials [in Spanish]. Arch Soc Esp Oftalmol. 2005;80(8):457-461.

10. Fox SA. Congenital ptosis. II: frontal sling. J Pediatr Ophthalmol. 1966;3:25-28.

11. Grover AK, Malik S, Choudhury Z. Recent advances in lid orbital and lacrimal surgery. In: Garg A, Pandey SK, Chang DF, Papadopoulas PA, Maloof AJ, eds. Advances in Ophthalmology. Vol 2. New Delhi, India: Jaypee Brothers Medical Publishers (P) Ltd; 2005:713-716.

12. Kakaiya R, Miller WV, Gudino MD. Tissue transplant-transmitted infections. Transfusion. 1991;31:277-284.

13. Houff SA, Burton RC, Wilson RW, et al. Human-to-human transmission of rabies virus by corneal transplant. N Engl J Med. 1979;300:603-604.

14. Martínez-Lage JF, Poza M, Sola J, et al. Accidental transmission of Creutzfeldt-Jakob disease by dural cadaveric grafts. J Neurol Neurosurg Psychiatr. 1994;57:1091-1094.

15. Duffy P, Wolf J, Collins G, DeVoe AG, Streeten B, Cowen D. Possible person-to-person transmission of Creutzfeldt-Jakob disease. N Engl J Med. 1974;290:692-693.

16. Uchiyama K, Ishida C, Yago S, et al. An autopsy case of Creutzfeldt-Jakob disease associated with corneal transplantation. Dementia. 1994;8:466-473.

17. Choe JM, Bell T. Genetic material is present in cadaveric dermis and cadaveric fascia lata. J Urol. 2001;166:122-124.

18. Carter SR, Meecham WJ, Seiff SR. Silicone frontalis slings for the correction of blepharoptosis: indications and efficacy. Ophthalmology. 1996;103:623-630.

19. Tillet CW, Tillet GM. Silicone sling in the correction of ptosis. Am J Ophthalmol. 1996;62:521-523.

20. Lamont M, Tyers AG. Silicone sling allows adjustable ptosis correction in children and in adults at risk of corneal exposure. Orbit. 2010;29:102-105. 
21. Bansal RK, Sharma S. Results and complications of silicone frontalis sling surgery for ptosis. J Pediatr Ophthalmol Strabismus. 2015;52:93-97.

22. Khan A, Majid O, Wani J. Fascia lata versus silicone sling frontalis suspension for correction of congenital blepharoptosis. Int J Med Sci Public Health. 2014;3:700-703.

23. Ali Z, Kazmi HS, Saleem MK, Shah AA. Silicon tube frontalis suspension in simple congenital blepharoptosis. J Ayub Med Coll Abbottabad. 2011;23:30-33.

24. Horng CT, Sun HY, Tsai ML. The impact of silicone frontalis Suspension with ptosis probe R for the correction of congenital ptosis on the Asian eyelids in Taiwan. Life Sci J. 2010;7:19-24.

25. Morris CL, Buckley EG, Enyedi LB, et al. Safety and efficacy of silicone rod frontalis suspension surgery for childhood ptosis repair. J Pediatr Ophthalmol Strabismus. 2008;45:280-288.

26. Simon GJB, Macedo AA, Schwarcz RM, et al. Frontalis suspension for upper eyelid ptosis: Evaluation of different surgical designs and suture material. Am J Ophthalmol. 2005;140:877-885.

27. Steinkogler FJ, Kuchar A, Huber E, Arocker- Mettinger E. Gore-Tex soft-tissue patch frontalis suspension technique in congenital ptosis and in blepharophimosis-ptosis syndrome. Plast Reconstr Surg. 1993;92:1057-1060. 